Article

\title{
Should All Cars Be Electric by 2025? The Electric Car Debate in Europe
}

\author{
Nathalie Ortar $1, *$ (i) and Marianne Ryghaug ${ }^{2}$ \\ 1 Laboratoire Aménagement Économie Transport, ENTPE-University of Lyon/CNRS, rue Maurice Audin, \\ 69518 Vaulx-en-Velin CEDEX, France \\ 2 Department of Interdisciplinary Studies of Culture, Faculty of Humanities, \\ Norwegian University of Science and Technology, Bygg 5, 5471, Dragvoll, Edvard Bulls veg 1, \\ 7491 Trondheim, Norway; marianne.ryghaug@ntnu.no \\ * Correspondence: nathalie.ortar@entpe.fr
}

Received: 22 February 2019; Accepted: 21 March 2019; Published: 28 March 2019

check for updates

\begin{abstract}
The car is still the most common mode of transport in Western countries, particularly so across the European Union, as it accounts for about two-thirds of daily commuting. So far, measures aiming to reduce automobile traffic and incentives for the modal shift to public transport and non-polluting methods of travel (walking, cycling, etc.) have had little effect. Moreover, the car lies at the core of a very complex system that has proven to be difficult to unlock. In light of these challenges, using new types of engine power may appear to be a solution. Electric vehicles have the potential to improve the efficiency, affordability, and sustainability of the transport system. However, there remains much uncertainty as to how such a transition from one type of engine to another may unfold, and where it could take place within the European context. In June 2017, the H2020 project SHAPE-ENERGY launched an online debate on the Debating Europe platform with the question: "Should all cars be electric by 2025?". The aim of the debate was to elicit citizens views on whether the goal could be reached, how and with which consequences. The diversity of the vantage points that have appeared in the subsequent discussion generated by the strands of debate allows us to bring into discussion the viewpoints and arguments that are not often addressed in the literature on the adoption of electric cars in a comprehensive way. The article sheds light on those debates across Europe, in order to bring new insights to European policymakers that are seeking to promote the market for electric vehicles. It also broadens the scope and offers important contributions to scholarly debates on the diffusion and adoption of such vehicles.
\end{abstract}

Keywords: electric mobility; energy justice; spatial justice; pollution

\section{Introduction}

Despite measures aiming to reduce automobile traffic and incentives for the modal shift to public transport and non-polluting methods of travel (walking, cycling, etc.), the car remains the most common means of transportation. It accounts for about two-thirds of daily journeys in Western countries such as France. Public transportation, on the other hand, covers less than $10 \%$ of the daily journeys of urban dwellers ([1], p. 130, [2]). Thus, transitioning away from our existing car-centred transportation system may very well be "the hardest case" of transitions [3]. In light of these challenges, electric vehicles (EVs) appear as a solution, with the potential to improve the efficiency, affordability, and sustainability of the transport system. The electrification of passenger transportation should also, in principle, lead to more resilient cities, improve the efficiency of the distribution network and challenge the sustainability of the existing grid [4], as well as reduce negative externalities such as 
pollution [5,6]. For these reasons, electric vehicles have become one of the most prominent technologies for decarbonising passenger transportation when coupled with a low-carbon energy system [7].

Despite these promises, there is much uncertainty with respect to how such a transition may unfold, and where it may take place. While the momentum around EVs is building, the stock of EVs remains at around $0.2-0.3 \%$ of the total global passenger fleet [8]. As of today, few countries in Western Europe seem to be transitioning at a quick pace towards electric passenger mobility, with the exception of Norway. Nonetheless, the European Commission has a target for achieving emissions-free transport by 2050 for passenger and commercial transport and will rely heavily on reducing $\mathrm{CO}_{2}$ emissions in new vehicles, to achieve this goal.

So far, the goal of reducing $\mathrm{CO}_{2}$ emissions in new vehicles has not directly translated into a corresponding growth in the EV market. Currently, the vast majority of Europe's new cars are gasoline or diesel powered, with a total market share of $93 \%$, while shares of hybrid-electric vehicles, and plug-in hybrid and battery-electric vehicles remain at 1.8\% and 1.1\% respectively, in the EU in 2015 [9]. Norway is again the exception, surpassing other European countries, with new EV car sales amounting to $28.9 \%$ of total new car sales [10]. Overall, there are also concerns that electric mobility may lead to a growth in electric power demand, which in turn might not contribute to $\mathrm{CO}_{2}$ emission reduction if the source of electricity comes from non-renewables [11]. In this light, it is interesting to debate the future of electric cars in a European context. Will the goals be reached, in what way and with which consequences?

In June 2017, the H2020 project SHAPE-ENERGY launched an online debate on the Debating Europe platform asking: "Should all cars be electric by 2025?". The aim of the platform is to help the Friends of Europe, a leading think tank dedicated to the creation of a more inclusive, sustainable and forward-looking Europe, foster debate around key issues for the European Union. This was one debate among several others, but was the one that received the most comments by far (325 in total). The point of the Debating Europe online platform is to invite citizens to express their opinions in English, in order to solicit reactions from politicians at the European level. In the presentation of the debate, two experts are interviewed, and they provide contradictory opinions about the future of EVs. Citizens are asked to take a position. The debates have two main functions. First, to provide information in a controversial way, thereby spurring debate among a wide public. Second, to produce a debate though the commentaries left by citizens, which will help bring more insightful information to EU policy makers. The debate has no moderation, and people have the choice to either follow a conversation by replying to a previously posted commentary, or add a new commentary.

In spite of this particular debate's numerous comments, citizen debates, and in particular, online discussion platforms, are never representative of the whole population [12]. The Internet or online format privileges certain groups of people and certain ways of talk over others [13]. Thus, participation is never equally accessible to all [14]. Papacharissi [15] has identified three issues related to the capacity of the Internet to improve the democratic exchange of ideas: access to information, the possibility of meeting people with different backgrounds and how the future is connected to the commercialization of this environment. However, greater access to information is not enough to make the public sphere more inclusive. The Internet may also become more fragmented, with a virtual mass of people being subdivided into small groups of interest. Finally, the mere existence of a virtual space does not guarantee democratic and rational discourse. Nonetheless, analysing online participatory applications that allow citizens to participate in public debate, where they express their opinions and suggestions, may be very valuable as a source of information about public understanding and deliberation of the issue for governance and policymaking purposes. As earlier research has shown, online debates can enhance political expression beyond the constraints of national boundaries, and they may contribute to the development of new forms of civic debate [16]. Although relatively few people remain optimistic regarding the role of the Internet as a technological force of democratisation and deliberation, the so-called Web 2.0 technologies that have been frequently mobilised with the goal of fostering new modes of public participation in politics [17], opening up for layperson participation in scientific 
debates [18], and serving as mechanisms to make different voices heard in deliberative processes [19]. The literature has further illustrated that by giving voice to deliberative reasoning, one engages in 'disciplining' elites, thereby encouraging those who usually dominate public debate to listen to the perspectives of others [13].

The online debate "Should all cars be electric by 2025?" also demonstrates that debaters can have very diverse backgrounds and different centres of interest: some people possess deep technological knowledge and others appear knowledgeable in the geopolitics of energy, while others yet focus more on the ecological and/or social impacts. In this respect, the online debate offers a unique vantage point from which to examine the various discussions surrounding EVs across Europe, and the different posts show signs of situated knowledge, perceived challenges, consequences, and effects-all reflecting the diversity of the geo-socio-economic contexts encountered across various European countries.

The diversity of those vantage points allows us to bring into discussion the viewpoints and arguments that are not often discussed in the literature on EV adoption in a comprehensive way. In this way, we are striving to align our research with marginalised voices, and we aim to avoid reproducing and reinforcing the power of the already dominant $[13,20]$. In this analysis, we have developed a non-traditional research focus on issues such as energy justice, renewable energy supply and the transformation of the energy (provision) system, as well as the ecological considerations (the longevity of cars, the production of cars, etc.), which are seldom investigated from a citizen perspective, particularly across different geographical and socio-economic spheres. The knowledge introduced by researchers, using the social practices theory, an overarching theory to frame discussions of social change, mostly informs and investigates the ways in which social practices persist and change [21]. Changes in this context imply a form of directional process that is present in the term 'transition' [22], which necessitates a directional change from one state to another. If those changes are necessary in the context of climate change, and the adoption of EVs might represent one possible solution, their effectiveness will then depend on how the European Union opts to deal with the several pathways of energy transition [23] and to what extent it takes into consideration energy justice and social impact [24].

In the following analysis, based on the online discussions organised through the SHAPE-ENERGY project and the Debating Europe platform, we will make salient the ways in which citizens are debating EVs across Europe. This, we believe will bring important and new insights to European policymakers who seek to promote the market for EVs in Europe, as well as broaden the scope of scholarly debates concerning the sustainability of the diffusion and adoption of EVs, as seen from the perspective of European citizens.

\section{Previous Research on EV Adoption}

The research literature has identified several barriers to EV diffusion, the most commonly mentioned being higher prices, limited driving distances, and a lack of charging infrastructure [25]. The higher price of electric cars in comparison to conventional cars is one of the most important barriers that are stressed in the literature [26]. Indeed, many potential EV users compare EVs with conventional vehicles solely based on the purchase price, which is often higher. Many are not aware of the various government incentive programs, and the fact that the total cost of EV ownership is lower than in the case of conventional vehicles, due to fuel savings and lower maintenance costs [26].

The lack of charging infrastructure is also considered to be one of the main barriers to EV market diffusion $[27,28]$, due to the fact that in case of insufficient charging infrastructure, EVs will not offer the flexibility and convenience that most drivers expect from their vehicles [26]. Access to battery charging varies significantly, and charging facilities other than those found at home are in short supply in many places [29].

The limited capacity of batteries results in a shorter driving range compared to conventional vehicles. This is often mentioned as a barrier to effective EV market implementation $[26,28,30]$ and widespread adoption of EVs [31]. Even though the theoretical capacity of EVs is sufficient for most 
daily trips, this barrier is known to manifest with regard to range, as both a technical and cognitive problem [32] as some experience 'range anxiety'. This is "the fear of being stranded in a [battery electric vehicle] because it has insufficient range to reach its destination" ([33], p. 723). Thus, as noted by Rezvani et al. [31], the restricted driving range is more of a perceived barrier than an actual one.

In addition to the three aforementioned factors (costs, charging infrastructure and range) that earlier research has identified as the most important barriers to EV adoption, other characteristics of EVs also worry potential buyers. Potential EV buyers are uncertain as to the extent that the use of EVs will actually lead to decreased $\mathrm{CO}_{2}$ emissions, and thus, how it will concretely benefit the environment [25]. They also question whether it may lead to increased energy demand and more emissions if it is not powered by renewable energy sources. Besides concerns over increased power demand, some potential EV drivers also consider the disposal of used batteries as being harmful to the environment, thereby raising uncertainty as to the environmental benefits of battery-electric vehicles [26]. Nonetheless, these aspects of EVs that relate to concerns about their environmental and climatic impact have been given less attention in the research literature on EV adoption than techno-economic factors.

Research studying real users of EVs has served to dismantle some of the barriers mentioned in most EV adoption studies that focus on potential adopters [31]. Two positive traits of EVs often mentioned by EV drivers are that they are pleasant to drive and they are practical $[34,35]$. Noise reduction is highlighted as being an important dimension to the pleasure of driving [36]. EVs also seem to introduce new driving practices and restructure the organisation of daily life [34] for some, but often in a rather undramatic way. Charging habits and charging frequency at home have proven to be less dependent on the intensity of daily use of the EV than on the confidence of the user in his or her mental conception of the autonomy of the vehicle [37]. Jarrigeon et al. [38] also shows that a symbolic shift occurs among users in the transition from a fossil fuel-powered vehicle to an EV, as powering the car is transformed from a punctual action into a familiar, daily practice. This shift contributed to trivializing the EV, making it progressively appear as just another car to its users. Others have found that the adoption of an EV increased the awareness of energy consumption, sensitised its users towards electricity use, and spurred pro-environmental values and interest in energy technology among some of its users [35]. Moreover, as EVs are often connected to a charging station, there are various opportunities for grid services based on EVs [39]. With additional reputational and related environmental benefits to companies, studies carried out in France and Germany also show that EVs meet the mobility needs of different commercial users [36,40,41]. The main challenges for the deployment of EVs are related to the lack of related infrastructure, market characteristics, and lack of experts in service-related sectors. However, in order to understand the future adoption patterns of EVs in Europe, it is not enough to study the experiences of real users and early adopters, and only in certain places where EV sales are ramping up. It is equally important to understand the expectations and concerns of the wider European public, and how various European citizens' reason around EVs, based on their own situated knowledge and experiences.

Before delving into these debates, we outline the specificities of the online debate, examining both its strengths and weaknesses in terms of enhancing our understanding of EV resistance among the public.

\section{Methods and Specificities of an Online Debate}

An online forum is an asynchronous computer-mediated communication device, allowing Internet users to exchange messages or to post their opinion on a particular topic. An online forum is thus an automatically archived form of electronic correspondence, produced interactively in a collective way [42]. In the case of the Debating Europe online debates that form the basis of our analysis here, the device offers its users a classification of the messages that are already posted in chronological order. The participants are then invited to react to the debate presented at the top of the page and 
to the messages previously posted online. This presentation leads participants to either continue a conversation, or to start a new thread related to the theme.

This type of corpus is ideal for the analysis of conversations [43], because the exchanges are produced in the absence of the analyst who records them, and homogeneity is defined by the recording device [44]. Archiving is established automatically, and it is a condition of which the participants are aware prior to participation. Discussion forums can thus be defined as hybrid interpersonal mass communication devices [45], to the extent that they allow both interpersonal exchange (A responds to $\mathrm{B}$ ) and mass communication (A posts a message readable by a potentially unlimited number of Internet users).

One of the limitations of this method is that, in many ways, it remains difficult to consider on-line discussions as real conversations. Indeed, it is impossible to identify the unity of the participatory framework of a forum in the sense that there is no defined group of participants. Rather, one has many participants who enter and leave the discussion. The duration of the discussion is another problematic parameter, because we cannot ensure that the exchanges in a given forum take place in a unified period. The temporal dimension is not absent from the forums (even if they are asynchronous devices), but it only determines the sequential organisation of the exchanges only very slightly, insofar as, for example, the second part of an adjacent pair (of the question-answer type) can be produced a very long time after the first post. This aspect, in addition to the archiving of data, makes it possible to define discussion forums as being persistent conversations [46], or "dynamic digital documents", archived in the process of being constituted [42]. We can therefore consider that online forums allow for discontinuous conversations taking place when the exchange of words is not the main activity of the participants, but an accompanying activity [47].

Finally, to post a message online through discussion forums requires one to explicitly choose the status of the intervention in the structuring of the debate (initiative versus reactive intervention?), the choice of the recipient (who is the message addressed to?) and the choice to either stay or to leave the debate. Regarding exchanges, when they are pursued, they constitute in general, a rather short sequence. In other words, it is rare for an initiating message to give rise to a very long thread.

Online debates have several biases: one being language as some have the ability to respond in their mother tongue while others rely on a foreign language to express themselves, and with varying degrees of mastery. Another is access (to the Internet) and knowledge of the debate, including having the time to meaningfully engage. These biases means that we do not expect participants of the debate to signify a representative sample of European citizens. Nonetheless, they comprise a heterogeneous sample of European citizens with different nationalities, and probably groups that are not attributed significant attention in the research literature on EVs.

The debate over the future of EVs in Europe comprised 25 conversations. However, despite the bias induced by the common language used (English), we assume that participants represented a wide range of nationalities (Belgium, France, Germany, Greece, Hungary, Ireland, Italy, Latvia, Norway, Romania, Spain, Sweden, United Kingdom, Ukraine), based on the examples they used to illustrate the statements. A look at the first names of the discussants also revealed the debate to be relatively gendered, with more male than female participants (although in a few cases it was difficult to ascertain the gender of the debater from their first name only).

The debate has been analysed by using TextSTAT-Simple Text Analysis Tool, which is a concordance program. The program analyses text corpora and displays word frequency lists and concordances to search terms. The function 'Citation' was used in the post-search phase to display texts passage with more context surrounding the words that were initially chosen as significant. Although the debate is open access and therefore public, we chose to use only the initials of the participants. The quotes have not been altered, but they were occasionally shortened in the interest of clarity, as a verbatim may deal with several issues. 'Electric' (88 occurrences) and 'electricity' (40) are unsurprisingly the most frequently mentioned terms, followed by 'yes' (63) and 'no' (59). It is also interesting to note that 'nuclear energy' appears 59 times and 'fossil fuels' 58 times, while renewable 
energy sources are mentioned 54 times. As such, those figures do not tell much, as for example, the use of nuclear is a known controversial issue. Nonetheless, this initial analysis allows us to see that the debate was rather balanced, with almost equal numbers answering yes and no. Most participants also turned out to have a more nuanced approach, and seemed to agree with the fact that EVs do not represent a simple and straightforward alternative to fossil fuels:

The very first reaction is yelling "Yes!" but think it twice. Wouldn't be better to say instead non-traditional fuel based cars? I mean electricity might not be the single solution and I don't refer uniquely to biomass or hydrogen, look around) (M. M. B. 20 June, 2017)

Energy dependency, the sustainability of car culture, wastes produced by EVs, and social and geographical inequality are the most important topics found in the debates. In the next few paragraphs, we will map and discuss these issues, as well as some issues that did not seem to be reflected in the online debate.

\section{Results}

\subsection{Solving Energy Dependency or Hampering Energy Security}

Energy is a major concern because of its geopolitical implications [48], and the dependency on fossil fuels is a major concern for most of the participants. As J. H. (20 June, 2017) and M. V. (20 June, 2017) put it, the implications are manifold: "Please get rid of humanity's dependence on oil (at least in the $E U)$ to usher in peace on earth (with regards to oil), independence, prosperity, cleaner air and to save the planet." "The smog in the big cities would be history, the price of oil will go down, Putin's source of money will go low, very low and peace would be easier to achieve! So many advantages!"

Many seemed to agree wholeheartedly that "all cars should be electric by 2025 ", and that oil as a source of air pollution is a major concern, as K. H. (27 August, 2017) writes: "Nice suggestion. But way too late. In Bulgaria, 20,000 (!) people a year die from suffocation due to air pollution." Others also point out that getting rid of oil is a major concern, and something that would benefit cities in particular, as this person writes: "The environmental benefits for large polluted cities will be huge https://www.bloomberg.com/features/2016-ev-oil-crisis/" (J. A. 20 June, 2017).

The strategy to phase out oil is also perceived to have other beneficiary effects. Some mention it as the safest way to avoid conflict: "Keeps EU countries out of conflicts related with oil and gas. Better invest all that money into harvesting the sun!" (T. B. 2 July, 2017). We see here that producing renewable electricity is seen to have positive effects beyond simply decarbonizing the energy system. Supporting EVs is seen as a way to hamper oil suppliers: "Definitely! My reasoning isn't based on fake ecology pretences but rather on putting some oil suppliers out of equation." (P. K. 6 November, 2017).

Despite the stated benefits of getting rid of oil, the production of electricity is a major concern voiced by many participants. In particular, increasing the supply of electricity without increasing ecological damage is a concern raised by many: "Electricity comes from either fossil fuels or the materials used to build plants that harvest alternative sources of energy likely lead to more geo-ecological damage and pollution than their use would prevent" (L. F. 12 December, 2017). There is also much discussion about the ability of renewable energy sources to produce enough energy to power an all-electric car fleet. Many believe that renewable energy sources would not be able to produce energy in sufficient amounts: "Where will we get electricity from? Wind, water, sun? Not makeable!" (J. U. 12 December, 2017). Some do, on the contrary, have a more positive outlook like J. Y., who refers to the success story of southern European countries: "Do it Portuguese-style Ivan, where $60 \%$ of our electricity on average comes from renewable sources! So there is a way." (J. Y. 27 August, 2017).

Again, the economic divide and different energy contexts in EU countries appear as a major concern that would impact the efficacy of EVs as a solution, as F. V. claims (21 June, 2017): "Not all European countries are as well-developed energy-wise as Sweden." Or as T. P. (2 July, 2017), who sees opportunities where others see challenges, puts it: "There is no need for coal or nuclear power plants, the 
wind mills from North and Baltic seas have an excess of energy that they waste because there is not a demand when they have strong winds. The battery from the cars could store this excess balancing the power grid."

Here, we can see that some participants possess quite a sophisticated understanding of the energy systems and the need to balance supply and demand according to the energy resource in use. To others, on the contrary, oil still seems to be inevitable in the production of energy, as voiced by this participant: "What's the deal? We stop using oil to make fuel but we use it to run power plants to get electricity for our cars?" (G. 20 June, 2017). Some feel that shifting to EVs would increase the dependency on neighbouring countries, as they would not be able to produce enough energy themselves: "Not all EU nations are producing enough spare energy to keep the demand for an electric car, so if we have to buy electricity from another country, it will only mean that they will be burning fossil fuel for us." (F. V. 21 June, 2017).

Overall, we note that there are opposing views on what a switch to EVs would entail for the energy system: for some, it would be a positive transition that, apart from cutting carbon emissions, would also strengthen energy security. For others, the increased demand for electricity would render their countries more dependent on other countries, and importing energy from abroad. The general concern is, however, that the required electricity would not be produced by renewable resources: "If we do it now, we will pollute much more because many countries still use coal power plants" (E. C. 12 December, 2017).

Rejecting fossil fuels, while at the same time stating the alleged inability of renewable to sustain the energy demand, made nuclear appear as an unavoidable solution to many: "As charging will happen predictably almost at the same time by the evening, when people arrive home from work, the peak of consumption will be much higher, so the installed capacity for electricity production probably needs to be much higher than that." (M. C. 6 November, 2017). This argument is also defended by A. G. (24 September, 2017) who states that: "If all cars are electric by 2025 we will need 20 more nuclear plants in Europe ... do the maths!"

Even those in favour of nuclear as a solution were dubious of its effectiveness over a shorter time frame (A. F. 20 June, 2017): "I personally agree that electric cars powered by nuclear power plants is the way to go, even with the problems that nuclear power presents in itself, but there is still a long way to go before it's feasible globally in Europe or elsewhere, and in no way it's going to be possible by 2025."

Many state that the required changes would come at a cost, raising concerns over who would pay for the transition (P. K. 6 November, 2017): "And who is going to pay for the huge investments in electric power production and distribution facilities?" Others raise the concern that, beyond simply having an effect on the production of electricity, using EVs would change the whole system: "There are many questions on this issue: the price of electricity, the costs of producing more and more electricity, the safety of having electric engines in case of catastrophes that cut us power." (T. S. 2 July, 2017)

\subsection{Should We Sustain a Car Culture?}

The question asked by Friends of Europe "Should all cars be electric by 2025?" also raised questions concerning the issue of car culture, which have been thoroughly debated among transportation and mobility scholars [49-51]. It fundamentally interrogates the automobile system as it has been developed over the last decades, where cars exist as part of a wider complex that involves material elements such as engines, tires, roads, and petrol stations, all linked together in a socio-material system [52-54]. In the online debate, we find traces of such ways of thinking, as participants point to the fact that "we can't afford to keep polluting the air" (C. B. 20 June, 2017), and to the importance of accelerating the transition, because "global warming does not wait until 2025 ... " (J. B. S. 27 August, 2017). It is also interesting to note that some of the participants voice that they are aware of the path dependency implied by the current socio-technical system that is built around cars, a dependency that is linked to the amount of waste that would be produced by changing the system, with the current car population being replaced by new vehicles.

The big lie about electric cars is two-fold. 1 the carbon emissions of manufacture are never factored into the equation, of course, spread over ten years because more often than not a car is scrapped after that. 2 the design model is flawed a car mostly is driven by one person at an average speed in the $20 \mathrm{~s} \mathrm{kph}$ and is designed crash at $140 \mathrm{kph}$. Car design should reflect of driving reality rather than false adverts. (A. P. 25 September, 2017) 
We also found that a systematic shift to EVs was perceived by some of the participants as "The car industry wish list for sales for the next 50 years" as written by A. P. (20 June, 2017) who also added a few months later that this was "the wet dream of the auto industry. Changing the world's car fleet in a decade. Good for Germany but not good for the planet." (12 December, 2017) while A. W. F. reacted even more violently, claiming that "The biggest lie and bullshit of our century!!! Another trick from the corrupt government \& criminal industry to fool the people ... " (20 June, 2017), thus, clearly expressing very skeptical opinions about the prospects of EVs and who would ultimately benefit from the shift. This anger seemed to be rooted in a mistrust of incumbent actors, including powerful actors, such as the (German) car industry, a mistrust tempered by others like M. C. who worries more about the costs and their social impacts:

I am not in the industry, but, as I know, it the break-even point to a new car built from scratch is in the millions or tens of millions of sold units. So we are expecting that the carmakers take a massive loss on cars newly introduced plus the electric cars that need to be yet researched, without giant subsidies from the public sector to the manufacturers? Is that it? Will that cost be redeemed how, and what is its social impact going to be? (6 November, 2017)

Taking those elements into consideration, some participants plead for a change in how transportation is organised, considering it to be inefficient, due to the land consumed (Y. C 5 July, 2017): "The car is still the most energy and space inefficient mode of transport, independently of how it is powered. [ ... ] Most trips in cities are below $10 \mathrm{~km}$. That's bikeable, if not e-bikeable. Cars simply should not be the norm if we are to become sustainable." They wish for the development of more extensive public transportation and/or alternative technologies, in order to lessen the dependency on EVs, as the only solution. O. D. claims (20 June, 2017):

Uniformization of transport modalities is as dangerous as thinking uniformization. A transport modalities policy mix must remain. Electric/Oil/Biofuel/hydrogen/Gasoil/Diesel/LPG at least for strategic matters. What about the risk of having all the electric cars unusable because of massive solar flares? Electric cars is an answer, an offer, it is not THE answer and must not be the unique answer to transport modalities by $2025 \ldots$

Along the same lines, another participant states that alternative solutions must also be developed, both for the sake of equity and to avoid battery shortages:

Not only electric ... hydrogen, pressurized air and other technologies. It must be open to all other options other than a combustion engine, otherwise there will be a huge battery crisis then ... and also allow a transition period for poorer people that can't afford expensive electric cars ... but need to move around for work and take kids to school ... (V. V., 6 November, 2017).

Thus, we see that the speed and the directionality of the transition is challenged by some of the participants, who not only fear the creation of a new technological lock-in, but who also see the consequences of the transition on social justice, as the capacity to adjust would have potential marginalising effects. We will come back to this point below.

The online participants appear to be knowledgeable regarding alternative car technologies such as hydrogen technologies as a sustainable solution that is capable of competing with petrol and diesel cars: "Hydrogen is pollution free and still uses the old style of petrol engine ... is safe and can produce on demand" (J. K. 20 June, 2017). Oil lobbies are among the actors who are blamed for the failure of these technologies to take off:

What kills me is that there are ways to run cars almost without fuel, and that those cars have been banned and boycotted. Panton engine, air compressed engine, even hydrogen and others. Lots of oil lobbies are behind this with the benediction of the governments who have no idea how to tax fuels if fuel is no longer necessary. (F. B. 27 August, 2017)

In general, it is interesting to note that even though some are skeptical of EVs (for different reasons), the skepticism surrounding the choice of electricity lies more in the perceived desire of imposing it as the only solution for sustaining car mobility, than in its effective use. For many debaters, EVs should be part of the solution, but the importance of the preservation of technological diversity emerges as being critical for addressing different needs. 
Finally, it is worth noting that the range anxiety that usually appears as a main constraint to EV development is only mentioned twice: first, in relation to the need to take into account social and geographical diversity, and second, in relation to doubts as to whom the change of system will benefit.

\subsection{Dealing with Waste}

One of the questions that engaged many participants was the production and management of cars and car batteries in a life cycle perspective. Many questioned in particular the handling of batteries after use (L. W. 12 December, 2017): "Why won't any one of these brain boxes tell me what is going to happen to the billions of scrapped cars and batteries, not to mention the batteries of the electric cars?". The afterlife management of pollution and waste was a major concern for the online participants.

The first subject of concern is one that is usually not mentioned in the literature; namely, what would happen to the old cars (L.W. 20 June, 2017): “Where are you going to dump all the petrol and diesel cars???". Others like J.B. also point out that the scrapping of old cars would create a chaotic situation (20 June, 2017) as it is "impossible to clear the old vehicles unless we want to create more chaos into a chaotic society. Good luck on that, the deadline is too short", while P. G. (14 September, 2017) states that: "The pollution from production and recycling is forgotten by most." Some point out that the grey energy needed for changing the system and its emissions were not taken into account in the life-cycle assessments (A. P. 25 September, 2017): "The big lie about electric cars is [that] the carbon emissions of manufacturers are never factored into the equation, of course, spread over ten years because more often than not a car is scrapped after that."

Beyond the challenge of producing enough clean energy and that of moving from one system to another without the production of additional waste, another concern raised by the participants related to the batteries themselves, as S. L. asks: "What about the battery? Are they really more ecological than petrol?" (24 September, 2017). "To the degree that we are aware today lithium is not increasing the concentration of atmospheric $\mathrm{CO} 2$ and thus affecting the planet's temperature. We solve problems with existing knowledge step by step. Using CO2 emitting transportation today is unacceptable" (E. 15 April, 2018). This view, however, is not widely shared, particularly since battery recycling levels are still very low: "Electric cars means another dangerous waste. What measure was done for this waste?" (M. 6 August, 2018).

Concerns over the recycling of batteries is very present in the debates, although it is often put into perspective against the urgent need to find a sustainable solution, as is emphasised here by an exchange between two participants:

C. S. (6 November, 2017): "What's the cost for recycling batteries, electric motors, transformers and transformer oils? What's the impact of these and of the energy used to charge the batteries?"

P. G. (6 November, 2017): “C. what's the cost of pollution on Health Care? What's the cost of diseases linked to pollution?"

C. S. (10 November, 2017) "I agree with that. Cooling oils for transformers are TOXIC. The acids of classic batteries and the metals used for high performance batteries are both toxic and difficult to recycle. So my question is valid and needs an answer."

Their cost is also a concern: "ANOTHER PROBLEM FOR ELECTRIC CARS [NOW] IS THE LIFE OF THE BATTERIES AND THEIR HIGH COST ... ” (P. L. 20 June, 2017). A solution could then be to increase the life-cycle of the cars, as stated by several participants such as A. P. (27 August, 2017):

The car needs to be regulated to real conditions. They are designed too big and too fast. They are also replaced long before their useful life is over. Greater regulation is needed to ensure max speed matches average speed. Carry capacity match user capacity. Working lifetime is stretched to forty years like the airframes. It is in the interests of the country without a car manufacturing industry to promote repairs and maintenance to keep cars on the road, it would mean more jobs in their country rather than manufacturing jobs. At the moment the emissions of manufacture are greater than the emissions of the car during its lifetime.

In other words, we see both discussions regarding the production and handling of batteries, and the scrapping of the present car population creating anxiety among these European citizens. 


\subsection{Social and Geographical Inequality}

Beyond the technological debate and the dependency on the current system, another concern raised by the participants dealt with social and geographical inequality. In most countries, EVs are more expensive to buy than petrol and diesel cars. Consequently, quickly replacing (older) petrol and diesel cars with EVs is not easy for the most impoverished households (N. A. 20 June, 2017): "Solve the vehicle replacement problem for the less fortunate! That has to be part of the solution!" The concern voiced by N.A. reminds us that automobility is part of a wider system that spans from energy production, to its distribution to the cars themselves. Those choices are technological and political, and they influence the everyday life of populations, as O. L. makes clear (20 June, 2017): "No [ . . ] the poorer of our society [... ] can't buy a new car each time there is a new idea in the political world." Thus, we clearly see evidence that to some, the electrification of personal cars seems like a top-down strategy that will only benefit the already wealthy, thus reinforcing unsustainable patterns of social injustice and inequality. Quite a few of those debating in the online forum voiced similar concerns around energy justice and the distributive effects of the strategy to shift to electric cars.

Energy justice was not only linked to socioeconomic status and the simple distinction made between the wealthy and the poor, but it was more specifically raised in relation to different spatial and geographical dimensions that risk the introduction of unequal footings and prospects for EV diffusion strategies. One such barrier mentioned was the difference between rural and urban dwellings: "City dwellers have forgotten that there are many places in Europe, where there is no mains electricity" (P.G. 14 September, 2017). Thus, we see that some point to a geographical divide that would privilege urban dwellers as opposed to those living in rural areas and in locations with less access to electricity.

If social differences are considered to be a strong barrier to a rapid spreading of $\mathrm{EV}$, they are perceived as even more so, when considering the differences between Eastern and Western Europe, as energy deprivation is known to be much higher in Eastern countries than in Western ones [55]. One participant, T. S. (27 August, 2017) expresses a similar viewpoint, stressing that: "Making such laws will practically ban mobility for low-income people including most of Eastern Europe." Both cultural and economic differences play into this line of reasoning. It is, for instance, stressed that the role of the car is different across Europe. While it has a very strong foothold in some parts of Europe, these are the same places where many people cannot afford an electric vehicle. P. X. responds (22 June, 2017) to the question of "will all cars be electric in 2025?" in the following way:

Yes but Not all of them! The replacement should be gradual in order people who rely on cheap used cars to be able to afford an electric one otherwise people in eastern and southern Europe will be unable to make a living! Since in our counties, a personal vehicle is the only way to go to your job is so important that in many cases that the first question that employers ask is "do you have a vehicle?

Some also link energy deprivation and lack of access of electricity in certain areas of Europe to obtaining access to a viable charging infrastructure. This is a concern also expressed by C. (21 June, 2017): "Where are we all gonna recharge it? ( . . ) don't forget that not all of us either leave on a place where we can charge our car easily nor there are batteries that can recharge in a matter of minutes, the same way that you take a few of them to refill your tank with petrol or diesel."

Thus, we see clear evidence that debates concerning the future of EV markets are linked to issues concerning energy security, sustainability, and energy justice [56].

In the next section, we will discuss the ways in which the online debates highlight different aspects related to the transition to EVs and electric mobility more generally, whereas the traditional research on EV adoption has been focused primarily on comparing EV characteristics to conventional vehicles, especially with regard to costs, range, and the infrastructure development needed $[57,58]$. We will, however, particularly accentuate the way in which citizen debates have managed to connect the debate on EVs to larger challenges in how to integrate EVs into existing energy systems, and the way in which EVs tie into questions concerning energy provision and demand, which again are connected to questions of energy security, energy justice, and sustainability. Let us begin with the last point: the sustainability of EVs, which was one of the most engaging questions for participants. 


\section{Discussion}

EVs pose one possible avenue toward cutting $\mathrm{CO}_{2}$ emissions from vehicles, and for shifting from a fossil-fuelled transport system to an electric one, a goal that is set by the EU and many other countries alike. Such a transition will not be unproblematic, as obstacles lie between it and the issues associated with affordability and finding an energy mix for producing electricity, which are capable of causing geographical divides, in both natural resources and recycling.

Cheap electricity may not always be available, and at peak loading times, there might be challenges in generating and maintaining enough capacity in the distribution grid [11]. Given the fact that renewable energy sources alone are probably not sufficient, and that many economies are planning to phase out nuclear energy, increased electricity demand may also be a challenge [11], even though the increased production of renewable energy and smart grid technologies, such as smart charging may alleviate these problems in the longer run [25] as new technologies appear. We might cite for example, smart charging and vehicles-to-grid $[4,59]$ which can lower costs and grid impact, for example, in the instance where the car is directly linked to a photovoltaic system [60].

As mentioned by the participants in the debates, the contribution of EVs to decarbonisation is contingent on the country's electricity generation mix, as the European situation regarding energy heavily depends on past choices, as well as regional socio-political situations [61]. While some countries, like Norway, mostly produce electricity from clean energy sources [10], other countries like Poland see the push towards EVs as a way to relaunch the coal mining industry [62], not to mention France, which remains heavily dependent on its nuclear industry and nuclear electricity production [63]. EVs have the capacity to help store renewable energy [59], particularly the new generation of vehicle-to-grid [4]. However this storage capacity depends on the robustness of the grid, and on how the local grid is linked to the wider network in order to function correctly [64], as territories across Europe do not have the same degree of access to electricity [61].

The issue of a geographical divide also exists within countries between urban and rural areas, the first being considered as more privileged, as the second is likely to have less access to electricity-even more so in the case of islands [65]. This issue is redflagged by scientists as being crucial for future investigation, as work that connects energy poverty with various concepts of justice has focused predominantly on inequalities between social groups, to the detriment of spatial forms of disadvantage [56]. However it has been acknowledged that the grid can restrain the expansion of the EVs market, as it depends on the development of infrastructure, especially the modernisation of the transmission and distribution system [66]. Through their concerns, participants in the debates highlighted the need for a 'whole-system' approach to deal with energy justice. Such an approach, already developed by some social scientists, highlights that an injustice experienced at the household level (in this case, energy poverty) can be the result of decisions and mechanisms operating elsewhere in the energy system $[56,67]$.

Affordability in both the domestic and the transport sector is thus a critical issue, which has high political salience $[68,69]$, as the issue of energy poverty is a key dimension of the broader energy justice paradigm [56]. Indeed, if low-income outer-suburban households are less car-deprived than urban ones, they are more likely to face another car-related transport disadvantage: car-related economic stress $[70,71]$, defined as the "financial stress associated with owning and operating cars, and its negative consequences" [72].

The affordability of EVs is also a key issue, as it has been stated that EVs may increase social gaps between various groups of populations, even in countries subsidising this type of consumption, as the wealthy are the most likely to benefit from these [73]. This may be reinforced by rises in electricity prices due to the increase in electricity demand if EVs start being used on a large scale [24]. The fact that range anxiety, which usually appears as a main constraint to EV development [6], is hardly mentioned, despite the very good knowledge of the pros and cons of EVs, is interesting as the debaters also mentioned the need to develop several solutions depending on the local energy mix and geography. 
Hydrogen is mentioned, although the costs of developing two types of infrastructures, one for each energy [74], is not taken into consideration.

EVs, as well as hydrogen-powered vehicles, do not change the car system [51], or only marginally, without affecting other significant changes in mobility [50]. The implication is that it will not change land consumption that is linked to the car, unless another form of mobility governance is developed in various territories [48]. A governance that will adopt a more systemic approach is needed.

Indeed, one of the most fascinating findings from the debate analysis is the recognised need to have a more systemic approach for transforming personal mobility, which is much in line with the recent concepts developed from within the sustainability transitions literature [75]. EVs are perceived as being just a new avatar to the car system, and their diffusion does not meet the requirements to mitigate land consumption, as the car ownership rate might not vary in the end (e.g., the same amount of on-street parking, and supply needed). Indeed, for the participants, thinking about EV deployment implies consideration for how cars are produced. The online debaters stress that the production of EVs requires resources, such as metals, electronic circuits, but also rare materials that may become subject to the scarcity of supply with increasing electric mobility [76]. Lithium, for example, is an essential component of batteries, but it is a resource that is difficult to extract, and whose exact contents of deposits and environmental impacts are difficult to evaluate. Recent estimates of global lithium resources have also reached very different conclusions, and there is disagreement as to whether the supply of lithium is adequate for supporting a future global fleet of electric vehicles [77,78]. Moreover, lithium is mostly present in Argentina, Bolivia and Chile [79], and it has become a huge financial resource for the region, but it could also become a source of destabilisation [80].

Indeed, practices of mobility can have a hard hegemonic or imperialist edge. Sheller ([81], pp. 251-252) reveals how the demand for materials needed in the car, such as aluminium, have been intimately tied to the discursive coproduction from other regions of the world as being backwards, slow, and relatively immobile [53]. The use of lithium might therefore be only a temporary solution, and this is all the more true when taking into consideration, as do the participants of the debates, the fact that the recycling of batteries is a complex and costly issue involving the use of a chemistry that is not yet fully mastered in order to give a second life to waste materials-although it might just be a matter of time before the process becomes more sustainable [82]. One might expect, however, that technological development would meet some of these challenges in the long-run as there is much R\&D effort being put into developing more sustainable batteries for the future [83].

Currently, in the literature, the development of 'green cars' such as EVs, is often seen as a way to ensure the sustainability and future of the automobile system, while maintaining value creation and employment in many European countries. To prepare national industries for a transition towards low-carbon societies, many European governments have created programmes to promote and develop EVs. The issue of green cars and new forms of mobility poses a strategic and economic challenge in many areas for firms and policy makers, and it is becoming an increasingly relevant consideration for the future of the automotive industry [84], in spite of a clear mistrust of incumbent actors, including powerful actors, such as the (German) car industry. It also makes visible an interesting contrast between public perceptions, on the one hand, and sustainability transitions research, on the other, that are clearly perceived to be the same group of actors (car manufacturers) hampering the transition [85].

\section{Conclusions}

In this article, we have shed light on how citizens are currently debating EVs across Europe, based on online discussions organised through the Shape Energy project and the Debating Europe platform. While many of the online debaters are positive toward EVs in general and highlight that the energy transition is not happening fast enough, they raise concerns that have often not been thoroughly debated in earlier research on EV adoption. Those arguments underline different unwanted aspects of the transition to EVs, and therefore deserve more attention. Citizens raise the issue that changing to EVs will only perpetuate the automobile system without learning lessons from the current one. 
Such a transition has several drawbacks. Though the online debaters agree on the need to moves away from oil for ecological reasons, they also stress the threat of energy security issues and the need for autonomy within the European context. Also, they are concerned about the fact that increased electricity needs might not be met by renewable energy sources. The online debates also reveal that citizens are aware and concerned about the inequality and distributional effects of shifting to EVs. Indeed, opting for EVs also raises issues of energy justice, and the debates enable a mapping to be made of the diversity of access to the grid across Europe, and the diversity of energy production, linked to various past and recent energy choices. They also stress the diversity of access within countries between rural and urban areas. For the online debaters, the adoption of EVs will thus only be possible if they have the capacity to fight social and spatial inequalities. Concerns are also raised about the price of the EVs.

The participants in the debate also question the sustainability and ecological effects of replacing the existing diesel and petrol car park with EVs. They point to challenges concerning the recycling of the batteries, as well as the pollution that is caused by battery production and the ecological footprint of batteries, but also to the social and ecological consequences of mineral exploitation and the limits of mineral resources. Thus, we believe that this analysis brings important and new insight to European policymakers who seek to promote the market for electric vehicles in Europe, as well to scholarly debates about the diffusion and adoption of EVs that have, to a limited degree, focused on these concerns. In the scholarly literature on EV adoption, citizens have often been treated as consumers, as passive market actors, or as receivers of new technologies. Transitions towards sustainable energy and transport systems will be wide-ranging and challenging, requiring extensive public support [86], and taking into consideration the concerns voiced by the citizens are important, as support will most likely happen only when transitions are perceived as being just, fair, sustainable and inclusive [87].

Author Contributions: Both authors have contributed to the analysis and writing of the article.

Funding: This project has received funding from the European Union's Horizon 2020 research and innovation programme under grant agreement No. 731264 .

Conflicts of Interest: The authors declare no conflict of interest.

\section{References}

1. Carré, J.-R.; Julien, A. La Mobilité Autogène: Marche, Bicyclette, Roller ... a-t-Elle Encore Une Place Dans Les Villes Du Xxième Siècle? In Regards Sociologiques; METL-DRAST: Paris-La-Défense, France, 1999.

2. Ries, R. Transports Urbains: Quelles Politiques Pour Demain? Commissariat Général au Plan: Paris, France, 2003.

3. Geels, F.W.; Kemp, R.; Dudley, G.; Lyons, G. (Eds.) Automobility in Transition. A Socio-Technical Analysis of Sustainable Transport; Routledge: New York, NY, USA, 2012.

4. Noel, L.; de Rubens, G.Z.; Kester, J.; Sovacool, B.K. Vehicle-to-Grid. A Sociotechnical Transition beyond Electric Mobility; Palgrave MacMillan: Basingstoke, UK, 2019.

5. Sovacool, B.K.; Kester, J.; Noel, L.; de Rubens, G.Z. Expert Perceptions of Low-Carbon Transitions: Investigating the Challenges of Electricity Decarbonisation in the Nordic Region. Energy 2018, 148, 1162-1172. [CrossRef]

6. Noel, L.; de Rubens, G.Z.; Sovacool, B.K.; Kester, J. Fear and Loathing of Electric Vehicles: The Reactionary Rhetoric of Range Anxiety. Energy Res. Soc. Sci. 2019, 48, 96-107. [CrossRef]

7. Ryghaug, M.; Skjølsvold, T.M. Nurturing a Regime Shift toward Electro-Mobility in Norway: Towards New Organizational Structures for the Development of Shared, Automated, Electric and Integrated Mobility. In The Governance of Smart Transportation Systems; Springer: New York, NY, USA, 2019.

8. International Energy Agency. Global Ev Outlook; IEA: Paris, France, 2018.

9. The International Council on Clean Transportation. European Vehicle Market Statistics, 2017/2018; ICCT: Berlin, Germany, 2018.

10. Anfinsen, M.; Lagesen, V.A.; Ryghaug, M. Green and Gendered? Cultural Perspectives on the Road towards Electric Vehicles in Norway. Transp. Res. Part D Transp. Environ. 2018, in press. [CrossRef]

11. EEA. Electric Vehicules in Europe; Publication Office of the European Union: Luxembourg, 2016. 
12. Kröger, S. (Ed.) Political Representation in the European Union. Still Democratic in Times of Crisis? Routledge: Abingdon-on-Thames, UK, 2014.

13. Coleman, S.; Moss, G. Under Construction: The Field of Online Deliberation Research. J. Inf. Technol. Politics 2012, 9, 1-15. [CrossRef]

14. Skjølsvold, T.M.; Ryghaug, M.; Swensen, E.F. Democracy or War? The Communication and Deliberation of the Climate Issue Online. Nord. J. Sci. Technol. Stud. 2015, 3, 22-33. [CrossRef]

15. Papacharissi, Z. The Virtual Sphere:The Internet as a Public Sphere. New Media Soc. 2002, 4, 9-27. [CrossRef]

16. Poplin, A.; Pereira, G.C.; Rocha, M.C.F. The Participatory Cube: A Framework for Analysis of Online Participation Platforms. In Planning Support Systems for Sustainable Urban Development; Geertman, S., Toppen, F., Stillwell, J., Eds.; Lecture Notes in Geoinformation and Cartography; Springer: Berlin, Heidelberg, 2013.

17. Cogburn, D.L.; Espinoza-Vasquez, F.K. From Networked Nominee to Networked Nation: Examining the Impact of Web 2.0 and Social Media on Political Participation and Civic Engagement in the 2008 Obama Campaign. J. Political Mark. 2011, 10, 189-213. [CrossRef]

18. Nowotny, H. Democratising Expertise and Socially Robust Knowledge. Sci. Public Policy 2003, 30, 151-156. [CrossRef]

19. Bollen, K. Liberal Democracy: Validity and Method Factors in Cross-National Measures. Am. J. Political Sci. 1993, 37, 1207-1230. [CrossRef]

20. Law, J.; Urry, J. Enacting the Social. Econ. Soc. 2004, 33, 390-410. [CrossRef]

21. Shove, E.; Trentmann, F.; Wilk, R. (Eds.) Time, Consumption and Everyday Life: Practice, Materiality and Culture; Berg: Oxford, UK; New-York, NY, USA, 2009.

22. Walker, G. The Dynamics of Energy Demand: Change, Rhythm and Synchronicity. Energy Res. Social Sci. 2014, 1, 49-55. [CrossRef]

23. Sarrica, M.; Brondia, S.; Cottone, P.; Mazzara, B.M. One, No One, One Hundred Thousand Energy Transitions in Europe: The Quest for a Cultural Approach. Energy Res. Soc. Sci. 2016, 13, 1-14. [CrossRef]

24. Chukwuka, M.G.; Sovacool, B.K.; Brown, M.A.; Jenkins, K.; Viriri, S.; Li, Y. Justice, Poverty, and Electricity Decarbonization. Electr. J. 2019, 32, 47-51.

25. Biresselioglu, M.E.; Kaplan, M.D.; Yilmaz, B.K. Electric Mobility in Europe: A Comprehensive Review of Motivators and Barriers in Decision Making Processes. Transp. Res. Part A Policy Pract. 2018, 109, 1-13. [CrossRef]

26. Haddadian, G.; Khodayar, M.; Shahidehpour, M. Accelerating the Global Adoption of Electric Vehicles: Barriers and Drivers. Electr. J. 2015, 28, 53-68. [CrossRef]

27. Pierre, M.; Jemelin, C.; Louvet, N. Driving an Electric Vehicle. A Sociological Analysis on Pioneer Users. Paper presented at the eceee 2009 SUMMER STUDY, Côte d'Azur, France, 1-6 June 2009.

28. Azadfar, E.; Sreeram, V.; Harries, D. The Investigation of the Major Factors Influencing Plug-in Electric Vehicle Driving Patterns and Charging Behaviour. Renew. Sustain. Energy Rev. 2015, 42, 1065-1076. [CrossRef]

29. Tietge, U.; Mock, P.; Lutsey, N.; Campestrini, A. Comparison of Leading Electric Vehicle Policy and Deployment in Europe; ICCT: Berlin, Germany, 2016.

30. Sierzchula, W.; Bakker, S.; Maat, K.; van Wee, B. The Influence of Financial Incentives and Other Socio-Economic Factors on Electric Vehicle Adoption. Energy Policy 2014, 68, 183-194. [CrossRef]

31. Rezvani, Z.; Jansson, J.; Bodin, J. Advances in Consumer Electric Vehicle Adoption Research: A Review and Research Agenda. Transp. Res. Part D 2015, 34, 122-136. [CrossRef]

32. Axsen, J.; Goldberg, S.; Bailey, J. How Might Potential Future Plug-in Electric Vehicle Buyers Differ from Current "Pioneer" Owners? Transp. Res. Part D 2016, 47, 357-370. [CrossRef]

33. Egbue, O.; Long, S. Barriers to Widespread Adoption of Electric Vehicles: An Analysis of Consumer Attitudes and Perceptions. Energy Policy 2012, 78, 717-729. [CrossRef]

34. Pierre, M.; Fulda, A.-S. Driving an Ev: A New Practice? How Electric Vehicle Private Users Overcome Limited Battery Range through Their Mobility Practice. Presented at the eceee 2015 SUMMER STUDY, Hyères, France, 1-6 June 2015.

35. Ryghaug, M.; Toftaker, M. A Transformative Practice? Meaning, Competence, and Material Aspects of Driving Electric Cars in Norway. Nat. Cult. 2014, 9, 146-163. [CrossRef]

36. Caron, C.; Garabuau-Moussaoui, I.; Pierre, M. La Transition Énergétique Au Prisme Des Logiques D’action: Diversité Et Dynamiques D’appropriation. In L'énergie Et Ses Usages Domestiques: Anthropologie D'une Transition En Cours; Ortar, N., Subrémon, H., Eds.; Pétra: Paris, France, 2018; pp. 131-150. 
37. Franke, T.; Krems, J.F. Understanding Charging Behaviour of Electric Vehicle Users. Transp. Res. Part F 2013, 21, 75-89. [CrossRef]

38. Jarrigeon, A.; Massot, M.-H.; Pierre, M.; Pradel, B. Les Routines Du Quotidien À L'épreuve De La Mobilité Électrique. Espace Populations Sociétés 2015, 1/2. [CrossRef]

39. Dost, P.K.-H.; Spichartz, P.; Sourkounis, C. Charging Behavior of Users Utilizing Battery Electric Vehicles and Extended Range Electric Vehicles within the Scope of a Field Test. IEEE Trans. Ind. Appl. 2018, 54, 580-590. [CrossRef]

40. Garabuau-Moussaoui, I.; Pierre, M. (Eds.) Pratiques Sociales Et Usages De L'énergie, Socio-Économie De L'énergie; Lavoisier, Editions Tec \& Doc: Paris, France, 2016.

41. Kolarova, V.; Kugler, U.; Calliari, D. Electric Vehicles in Commercial Fleets: Potentials and Challenges from the User Perspective in Germany. Presented at the 7th Transport Research Arena TRA 2018, Vienna, Austria, 16-19 April 2018.

42. Marcoccia, M. L'animation D'un Espace Numérique De Discussion: L'exemple Des Forums Usenet. Doc. Numér. 2001, 5, 15-26. [CrossRef]

43. Marcoccia, M. L'analyse Conversationnelle Des Forums De Discussion: Questionnements Méthodologiques. Les Carnets du Cediscor 2004, 8, 23-37.

44. Maingueneau, D. L'analyse Du Discours. Introduction Aux Lectures De L'archive; Hachette: Paris, France, 1991.

45. Baym, N.K. The Emergence of on-Line Community. In Cybersociety 2.0: Revisiting Computer-Mediated Communication and Community (New Media Cultures); Jones, S.G., Ed.; Sage Publications, Inc.: Thousand Oaks, CA, USA, 1998; Volume 2.

46. Erickson, T. Persistant Conversation: An Introduction. J. Comput.-Mediat. Commun. 1999, 4. [CrossRef]

47. Goffman, E. Forms of Talk. Philadelphia; University of Pennsylvania Press: Philadelphia, PA, USA, 1981.

48. Urry, J. Governance, Flows, and the End of the Car System? Glob. Environ. Chang. 2008, 18, 343-349. [CrossRef]

49. Miller, D. Car Culture; Berg: Oxford, UK; New York, NY, USA, 2001.

50. Dennis, K.; Urry, J. After the Car; Polity Press: Malden, MA, USA, 2009.

51. Freudendal-Pedersen, M. Mobility in Daily Life: Between Freedom and Unfreedom; Routledge: Abingdon-on-Thames, UK, 2016.

52. Featherstone, M.; Thrift, N.; Urry, J. Automobilities; Sage: Londres, UK, 2004.

53. Sovacool, B.K. Experts, Theories, and Electric Mobility Transitions: Toward an Integrated Conceptual Framework for the Adoption of Electric Vehicles. Energy Res. Soc. Sci. 2017, 27, 78-95. [CrossRef]

54. Urry, J. The 'System' of Automobility. Theory Cult. Soc. 2004, 21, 25-39. [CrossRef]

55. Bouzarovski, S.; Herrero, S.T.; Ürge-Vorsatz, D. Unpacking the Spaces and Politics of Energy Poverty: Path-Dependencies, Deprivation and Fuel Switching in Post-Communist Hungary. Int. J. Justice Sustain. 2016, 21, 1151-1170. [CrossRef]

56. Jenkins, K.; McCauley, D.; Heffron, R.; Stephan, H.; Rehner, R. Energy Justice: A Conceptual Review. Energy Res. Soc. Sci. 2016, 11, 174-182. [CrossRef]

57. Bjerkan, K.Y.; Nørbech, T.E.; Nordtømme, M.E. Incentives for Promoting Battery Electric Vehicle (Bev) Adoption in Norway. Transp. Res. Part D Transp. Environ. 2016, 43, 169-180. [CrossRef]

58. Hidrue, M.K.; Parsons, G.R.; Kempton, W.; Gardner, M.P. Willingness to Pay for Electric Vehicles and Their Attributes. Resour. Energy Econ. 2011, 33, 686-705. [CrossRef]

59. Erdogane, N.; Erden, F.; Kisacikoglu, M. A Fast and Efficient Coordinated Vehicle-to-Grid Discharging Control Scheme for Peak Shaving in Power Distribution System. J. Mod. Power Syst. Clean Energy 2018, 6, 555-566. [CrossRef]

60. Dittus, H.; Kugler, U.; Schmitt, M.; Özdemir, E.D. Project Initiative-Bw-Real-World Driving, Energy Demand, User Experiences and Emissions of Electrified Vehicle Fleets; Institute of Vehicle Concepts, German Aerospace Center (DLR): Koeln, Germany, 2016.

61. Bouzarovski, S.; Herrero, S.T. The Energy Divide: Integrating Energy Transitions, Regional Inequalities and Poverty Trends in the European Union. Eur. Urban Reg. Stud. 2017, 24, 69-86. [CrossRef]

62. Lis, A. Making a Polish Electric Vehicle: Constructing a Green Future with Black Capital. In Ethnographies of Power: Citizenship, Government and Violence Along the Energy Grid; Loloum, T., Abram, S., Ortar, N., Eds.; Berghan: New York, NY, USA, 2019.

63. Zonabend, F. La Presqu'île Au Nucléaire. Three Mile Island, Tchernobyl, Fukushima... Et Après? Odile Jacob: Paris, France, 2014. 
64. Watts, L. Energy at the End of the World. An Orkney Islands Saga; The MIT Press: Cambridge, MA, USA, 2019.

65. Bouly de Lesdain, S. Petits Producteurs En Énergie Solaire En Corse. In L'énergie Et Ses Usages Domestiques. Anthropologie D'une Transition En Cours; Ortar, N., Subrémon, H., Eds.; Pétra: Paris, France, 2018; pp. 115-130.

66. Walkowiak, M. The Efficiency of Electric Cars for Mitigating Co2 Emissions in Poland. Res. Pap. Econ. Financ. 2016, 1, 55-61. [CrossRef]

67. McCauley, D.; Heffron, R.J.; Stephan, H.; Jenkins, K. Advancing Energy Justice: The Triumvirate of Tenets. Int. Energy Law Rev. 2013, 32, 107-110.

68. Mattioli, G.; Lucas, K.; Marsden, G. Reprint of Transport Poverty and Fuel Poverty in the Uk: From Analogy to Comparison. Transp. Policy 2018, 65, 114-125. [CrossRef]

69. Preston, I.; White, V.; Thumim, J.; Bridgeman, T. Distribution of Carbon Emissions in the Uk: Implications for Domestic Energy Policy; Joseph Rowntree Foundation: London, UK, 2013.

70. Belton Chevallier, L.; Motte-Baumvol, B.; Fol, S.; Jouffe, Y. Coping with the Costs of Car Dependency: A System of Expedients Used by Low-Income Households on the Outskirts of Dijon and Paris. Transp. Policy 2018, 65, 79-88. [CrossRef]

71. Ortar, N. Dealing with Energy Crises: Working and Living Arrangements in Peri-Urban France. Transp. Policy 2018, 65, 72-78. [CrossRef]

72. Mattioli, G.; Lucas, K.; Marsden, G. The Affordability of Household Transport Costs: Quantifying the Incidence of Car-Related Economic Stress in Great-Britain; UTSG: Bristol, UK, 2016.

73. Talantsev, A. Who Gains and Who Loses in the Shift to Electric Vehicules: Impact Assessment through Multi-Criteria Multi-Stakeholders Analysis. Procedia Environ. Sci. 2017, 37, 257-268. [CrossRef]

74. van Bree, B.; Verbong, G.P.J.; Kramer, G.J. A Multi-Level Perspective on the Introduction of Hydrogen and Battery-Electric Vehicles. Technol. Forecast. Soc. Chang. 2010, 77, 529-540. [CrossRef]

75. Steward, F. Transformative Innovation Policy to Meet the Challenge of Climate Change: Sociotechnical Networks Aligned with Consumption and End-Use as New Transition Arenas for a Low-Carbon Society or Green Economy. Technol. Anal. Strateg. Manag. 2012, 24, 331-343. [CrossRef]

76. Institute, Öko. Global Emission Model for Integrated Systems (Gemis) V.4.8; Öko-Institut: Freiburg, Germany, 2012.

77. Gruber, P.W.; Medina, P.A.; Keoleian, G.A.; Kesler, S.E.; Everson, M.P.; Wallington, T.J. Global Lithium Availability. J. Ind. Ecol. 2011, 15, 760-775. [CrossRef]

78. Speirs, J.; Contestabile, M.; Houari, Y.; Gross, R. The Future of Lithium Availability for Electric Vehicle Batteries. Renew. Sustain. Energy Rev. 2014, 35, 183-193. [CrossRef]

79. Vikström, H.; Davidsson, S.; Höök, M. Lithium Availability and Future Production Outlooks. Appl. Energy 2013, 110, 252-266. [CrossRef]

80. Revette, A.C. This Time It's Different: Lithium Extraction, Cultural Politics and Development in Bolivia. Third World Quart. 2017, 38, 149-168. [CrossRef]

81. Sheller, M. Aluminum Dreams: The Making of Light Modernity; MIT Press: Cambridge, MA, USA, 2014.

82. Larcher, D.; Tarascon, J.M. Towards Greener and More Sustainable Batteries for Electrical Energy Storage. Nat. Chem. 2014, 7, 19-29. [CrossRef]

83. Winslow, K.M.; Laux, S.J.; Townsend, T.G. A Review on the Growing Concern and Potential Management Strategies of Waste Lithium-Ion Batteries. Resour. Conserv. Recycl. 2018, 129, 263-277. [CrossRef]

84. Hildermeier, J.; Villareal, A. Shaping an Emerging Market for Electric Cars: How Politics in France and Germany Transform the European Automotive Industry. Eur. Rev. Ind. Econ. Policy 2011. Available online: http:/ / revel.unice.fr/eriep/index.html?id=3329 (accessed on 15 March 2019).

85. Geels, F.W. Regime Resistance against Low-Carbon Transitions: Introducing Politics and Power into the Multi-Level Perspective. Theory Cult. Soc. 2014, 31, 21-40. [CrossRef]

86. Ryghaug, M.; Skjølsvold, T.M.; Heidenreich, S. Creating Energy Citizenship through Material Participation. Soc. Stud. Sci. 2018, 48, 283-303. [CrossRef] [PubMed]

87. Ortar, N.; Subrémon, H. (Eds.) L'énergie Et Ses Usages Domestiques. Anthropologie D'une Transition En Cours; Europe et ses terrains, Ed.; Pétra: Paris, France, 2018.

(C) 2019 by the authors. Licensee MDPI, Basel, Switzerland. This article is an open access article distributed under the terms and conditions of the Creative Commons Attribution (CC BY) license (http:/ / creativecommons.org/licenses/by/4.0/). 